DOI: 10.46340/eujem.2021.7.5.3

Oksana Kostiuchenko

ORCID ID: https://orcid.org/0000-0002-2712-4308

Taras Shevchenko National University of Kyiv, Ukraine

Nataliia Baldych, PhD in Public Administration

ORCID ID: https://orcid.org/0000-0002-1434-4299

Taras Shevchenko National University of Kyiv, Ukraine

\title{
LEGALIZATION OF GAMBLING IN UKRAINE: HOW TO PREVENT NEGATIVE MANIFESTATIONS
}

\author{
Оксана Костюченко \\ Наталія Балдич, к. н. $з$ держ. упр. \\ Київський начіональний університет імені Тараса Шевченка, Україна
}

\section{ЛЕГАЛІЗАЦІЯ АЗАРТНИХ ІГОР В УКРАЇНІ: ЯК ЗАПОБІГТИ НЕГАТИВНИМ ПРОЯВАМ}

\begin{abstract}
In this article, the authors attempt to identify, study and compare the positive and negative consequences of legalization of gambling and found that the impact of gambling on society is both positive and negative and depends on a number of factors, including the environment, types of gambling available, as well as the effectiveness of public policy in the field of gambling regulation. Such research can be an essential basis for the development of an optimal model of fuses for possible negative manifestations of gambling. The relevance of this study is due to the fact that in Ukraine gambling has been outlawed for more than eleven years, due to which there was no natural development of the gambling business, neither in the legal field, nor in terms of social responsibility of the gambling industry. After the transition of the gambling business to the legal sphere of economic activity in the second half of 2020, the gambling market finally started working legally (however, the first licenses were granted to gambling industry entities in Ukraine only in early 2021). At the same time, this situation has caused increased public concern due to previous negative experiences, the widespread negative reputation of gambling and various doubts about the ability of the new law to become an effective guarantee of the safe operation of gambling for society. In order to provide answers to these and related questions, the authors analyzed the legally established environment for the operation of gambling in Ukraine and provided sound proposals for improving mechanisms aimed at preventing the negative manifestations of gambling. In particular, additional precautionary measures are proposed to increase the social responsibility of gambling organizers, which will serve as a reliable safeguard so that gambling as a form of entertainment does not become a threat to the safety and well-being of citizens.
\end{abstract}

Keywords: gambling business, gambling, legalization of gambling business, legalization of gambling, prohibition of gambling business, prohibition of gambling.

Постановка проблеми. Досить тривалий час, а це більше одинадцяти років, азартні ігри в Україні перебували поза законом. За таких умов не відбувалося природнього розвитку грального бізнесу ні в правовій площині, ні з точки зору соціальної відповідальності гральної індустрії. Після переходу грального бізнесу до легальної сфери господарської діяльності у зв'язку з прийняттям Закону України від 14.07.2020 № 768-IX «Про державне регулювання діяльності щодо організації та проведення азартних ігор» ринок азартних ігор нарешті запрацював у законний спосіб. Тож сьогодні питання, бути чи ні азартним іграм в Україні, вирішене законодавцем на користь останніх, проте градус напруги не спадає, а дискусія в суспільстві наразі продовжується, висловлюються позиції як за, так і проти легалізації азартних ігор. 
Питання грального бізнесу завжди було досить непростим і стосовно нього немає єдиної думки, - відмічають ті, які не байдужі до цієї тематики ${ }^{1}$, оскільки «з одного боку легалізувати не можна, бо кожен матиме доступ до гральних автоматів, у тому числі й діти, а з іншого - заборонити теж не можна, бо це означає лише те, що ситуація буде загнана «в тінь». Сукупність зазначених факторів обумовлюють потребу в дослідженні й порівнянні позитивних і негативних наслідків легалізації грального бізнесу та пошуці оптимальної моделі запобіжників негативним його проявам.

Аналіз останніх досліджень і публікацій. Питанню азартних ігор присвячена чимала кількість наукових досліджень. Зокрема, природу азартних ігор та діяльність усфері грального бізнесу досліджувати такі науковці, як М. Погорецький${ }^{2}, 3$. Топорецька ${ }^{3}$. Питання суспільної небезпечності зайняття гральним бізнесом висвітлені у працях О. Гладуна ${ }^{4}$, проблеми та запобіжні заходи у працях ${ }^{5}$. Також проблематика легалізації азартних ігор в Україні висвітлена в дослідженнях А. Овчаренка ${ }^{6}$, К. Торгашової ${ }^{7}$ В. Михайлової ${ }^{8}$; особливостям функціонування грального бізнесу в контексті розвитку туризму в Україні присвячено дослідження 9 . Значна увага в згаданих дослідженнях присвячена вивченню економічного та соціального впливу азартних ігор, а також обгрунтуванню доцільних заходів держави для скорочення втрат або збільшення вигід від провадження діяльності з організації та проведення азартних ігор.

Водночас численні дослідження грального бізнесу в Україні присвячені періоду, коли гральний бізнес в Україні був забороненим, тому здебільшого наукові роботи присвячені криміналістичному аспекту цієї діяльності та проблематиці ії легалізації. У вітчизняних наукових працях цього періоду мало досліджувався соціальний вплив азартних ігор та практично не розроблялися запобіжники негативному соціальному впливу, які могла б запроваджувати держава за умов легального функціонування цього ринку. У зв'язку з цим, віддаючи належне зазначеним дослідникам та їх роботам, в умовах, коли гральний бізнес введений в легальне поле діяльності, потребує комплексного аналізу розвиток державного регулювання грального бізнесу в контексті створених запобіжників можливих негативних проявів азартних ігор на тлі підвищеного суспільного занепокоєння.

Цілі статті полягають у виявленні позитивних і негативних наслідків легалізації грального бізнесу, аналізі законодавчо встановлених умов функціонування азартних ігор в Україні та наданні обгрунтованих пропозицій щодо удосконалення превентивних механізмів, спрямованих на запобігання негативним проявам азартних ігор.

Виклад основного матеріалу дослідження. Азартні ігри завше були невід'ємною частиною людської життєдіяльності та займали відповідне місце у соціальній сфері, не залежно від рівня їх сприйняття різними групами суспільства. Справедливість цього твердження доведена численними історичними дослідженнями, якими достеменно встановлено, що так чи інакше, азартні ігри займали певну нішу в соціокультурному житті всіх, без винятку, народів світу. Стосовно часового горизонту наразі немає одностайної позиції істориків, коли саме у світі з'явились азартні ігри. За різними

\footnotetext{
${ }^{1}$ Павлучкович, X. (2017). Заборонити не можна узаконити. Чи вдасться уряду легалізувати азартні ігри? Громадський портал Львова Форпост <https://forpost.lviv.ua/txt/suspilstvo/6902-zaboronyty-ne-mozhnauzakonyty-chy-vdastsia-uriadu-lehalizuvaty-azartni-ihry>. (2021, серпень, 29).

${ }^{2}$ Погорецький, М. А. (2015). Розслідування зайняття гральним бізнесом. Київ. Алтера.

${ }^{3}$ Погорецький, М. А., Топорецька, 3. М. (2014). Гральний бізнес: історія та правове регулювання. Київ: Дакор.

${ }^{4}$ Гладун, О. 3. (2014). Суспільна небезпечність зайняття гральним бізнесом. Наукові записки Інституту законодавства Верховної Ради Украӥни, 4, 81-85 <https://instzak.com/index.php/journal/article/view/670/672>. (2021, серпень, 29).

${ }^{5}$ Рябчук, С.В. (2018). Загальносоціальне запобігання гральному бзнесу в Україні. Право і суспільство, 3, 230-235 <http://www.pravoisuspilstvo.org.ua/archive/2018/3_2018/part_2/39.pdf>. (2021, серпень, 29).

${ }^{6}$ Овчаренко, А.Є. (2018). Легалізація грального бізнесу на теренах України. Молодий вчений, 4 (56), $734-738$ <http://molodyvcheny.in.ua/files/journal/2018/4/169.pdf>. (2021, серпень, 29).

7 Торгашова, К. О. (2019). Доцільність легалізації грального бізнесу в Україні. Young Scientist», № 4 (68), $433-436$ <http://molodyvcheny.in.ua/files/journal/2019/4/97.pdf>. (2021, серпень, 29).

${ }^{8}$ Михайлова, В. Д. (2020). Гральний бізнес як механізм тіньової економіки країни. Стратегія інноваційного оновлення економіки Украӥни в сучасних умовах : збірник тез допоповідей Всеукраїнської науково-практичної Інтернет-конферениії (Маріуполь, 26 березня 2020 р.), 189-191 < http://eir.pstu.edu/handle/123456789/26320>. (2021, серпень, 29).

${ }^{9}$ Гищук, Р.М., Бойко, І.Д. (2017). Особливості функціонування грального бізнесу в європейських країнах та їхній досвід у контексті розвитку туризму в Україні. Вісник Чернівецького торговельно-економічного інституту, 1-2 (65-66), 258-270 < http://www.chtei-knteu.cv.ua/herald/content/download/archive/2017/ v1-2/NV-2017-v1-2_27.pdf >. (2021, серпень, 29).
} 
оцінками науковців, їх розвиток розпочався ще за часів Давньої Греції, а перші прототипи казино та лотереї широко використовувались у Римі, Франції, Англії та Китаї. До прикладу, у залишках матеріальної культури древньої людини археологами знайдені предмети, які застосовувались в азартних іграх у Єгипті ще за 3500 років до н. е. ${ }^{1}$.

За тисячоліття історії ставлення до азартних ігор, як і до інших форм людських пристрастей, звичайно, змінювалось. Сьогодні всі держави світу, в принципі, визначилися з тим, яким чином вирішувати це питання. За оцінками експертів, у кожній країні щодо існуючого різновиду азартних ігор діють окремі закони. Тому навіть у країнах, де азартні ігри легалізовані, в кінцевому підсумку все залежить від того, які види азартних ігор допускаються на ринок. При цьому окреме важливе місце посідає питання прийнятності для країни функціонування азартних ігор офлайн та онлайн, чи лише офлайн.

Загалом, у сучасному світі всі держави по відношенню до азартних ігор умовно прийнято розділяти на три категорії: 1) категоричних противників азартних ігор, які їх взагалі забороняють; 2) менш негативно налаштованих (допускається часткова легалізація); 3) лояльно налаштованих, які встановлюють загально дозвільний режим азартних ігор (повна легалізація).

До першої категорії країн, де встановлена жорстка заборона на будь-які азартні ігри, належать такі країни, як, наприклад, Кіпр, Північна Корея (проте дозволені для туристів з екскурсіями), Об’єднані Арабські Емірати, Сінгапур, Камбоджа, Китай (окрім Макао та Гонконгу), Афганістан, Пакистан, Саудівська Аравія, Іран, Бахрейн, Кувейт, Катар, Оман, Бутан, Бруней, Азербайджан, Індонезія, Таїланд, Алжир, Лівія, Судан, Кайманові острови, Ватикан, Пакистан, ЦентральноАфриканська республіка ${ }^{2}$. Серед основних причин такого негативного ставлення до азартних ігор виділяють, в основному, такі: концепція азартних ігор суперечить культурі й етиці цих країн, релігійним уподобанням або рівню життя громадян. Водночас, деякі з цих країн розглядають питання щодо можливості легалізації грального бізнесу за певних умов та обставин.

Варто додати, що тотальна заборона азартних ігор діяла також і в Україні у період з червня 2009 року (25.06.2009 набув чинності Закон України від 15.05.2009 № 1334-VI «Про заборону грального бізнесу в Україні») до серпня 2020 року (12.08.2020 набув чинності Закон України від 14.07.2020 № 768-IX «Про державне регулювання діяльності щодо організації та проведення азартних ігор»).

До другої категорії менш негативно налаштованих до азартних угор, або іншими словами «виважено» лояльних, належать країни, які дозволяють лише певні види азартних ігор та/або встановлюють на них державну монополію, або встановлюють обмеження щодо кількості гральних закладів, які можуть діяти одночасно. Зокрема, до цієї групи відносяться майже всі країни ЄС (Франція, Фінляндія, Данія, Австрія та інші), в яких азартні ігри легалізовані, проте встановлена державної монополії на організацію та проведення азартних ігор, яка проявляється в різних формах. Наприклад, дозвіл на проведення азартних ігор виключно для однієї компанії, яка повністю або частково перебуває в державній власності (Франція - єдиний оператор Francaise des Jeux для казино, Данія - компанія Danske Spil A/S, 80 \% якої належить державі, 10 \% Федерації спорту Данії та $10 \%$ Асоціації гімнастики і спорту). У деяких інших європейських країнах встановлено обмеження щодо кількості гральних закладів. Наприклад, в Австрії та Словенії щодо максимальної кількості казино, у Фінляндії та Греції - щодо максимальної кількості суб'єктів, які можуть одночасно діяти на ринку азартних ігор з одночасним обмеженням кількості гральних закладів ${ }^{3}$. До таких країн також належить і Норвегія, де всім гральним бізнесом керує держава, під управлінням якої перебувають дві норвезькі компанії, які мають право займатися діяльністю, пов'язаною з азартними іграми, - це Norsk Tipping та Norsk Rikstoto ${ }^{4}$.

\footnotetext{
${ }^{1}$ Вестник игорного бизнеса (2021). Игорный бизнес в мире

$<$ http://vib.adib92.ru/main.mhtml?PubID=9164\&Part=12> (2021, вересень, 14).

${ }^{2}$ Погорецький, М. А., Топорецька, 3. М. (2014). Гральний бізнес: історія та правове регулювання.

Київ: ВД Дакор, 53-61. Овчаренко, А. С. (2018). Легалізація грального бізнесу на теренах України. Молодий вчений, 4 (56), 734-738 <http://molodyvcheny.in.ua/files/journal/2018/4/169.pdf>. Vishruti Chauhan (2020).

Gambling laws across the world. iPleaders <https://blog.ipleaders.in/gambling-laws-across-world>.

(2021, серпень, 29).

${ }^{3}$ Погорецький, М. А., Топорецька, 3. М. (2014). Гральний бізнес: історія та правове регулювання. Київ. ВД Дакор. 53-61.

${ }^{4}$ Панасицька, О., Іванцова, А., Чек, В. (2021). Ігри в законі: як регулюють гральний бізнес в Україні та у світі. Вокс Україна <https://voxukraine.org/igri-v-zakoni-yak-regulyuyut-gralnij-biznes-v-ukrayini-ta-u-sviti>.

(2021, серпень, 29).
} 
У такій країні, як Японія, азартні ігри довгий час були незаконні, але нещодавно були легалізовані ставки на спортивні заходи, а також відкриті різні казино ${ }^{1}$. Також до цієї групи входять країни, які дозволяють проведення азартних ігор лише успеціально відведених зонах, як, наприклад, Росія.

До третьої категорії країн, які досить лояльно налаштовані по відношенню до азартних ігор, належать країни, які надають доступ до широкого кола азартних ігор та допускають на ринок велику кількість компаній за умови дотримання певних кваліфікаційних, організаційних, фінансових та інших вимог і лише деякі види азартних ігор забороняють. До таких країн, зокрема, належать Індія, Великобританія, США, Макао та Гонконг (Китай), Австралія, Ірландія, Фінляндія, Канада, Таїланд і Нова Зеландія, які вважаються одними з основних ринків для грального бізнесу ${ }^{2}$,

До цієї категорії країн також входила і Україна до 2009 року. Наразі Україна також належить до цієї категорії, оскільки дозволеними стало широке коло азартних ігор як офлайн, так і онлайн, а на ринок допускається необмежене коло організаторів будь-якої форми власності.

Однак окремої уваги в силу своєї легкодоступності та складнощів уконтролюванні заслуговують азартні ігри, які проводяться онлайн. Навіть у тих країнах, де встановлені жорсткі правила щодо азартних ігор, в онлайн середовищі вони можуть «жити» свої життям. Ситуація 3 функціонуванням онлайн гемблінгу в 2021 році в різних країнах світу, за оцінками експертів, наведена на рис. 1.

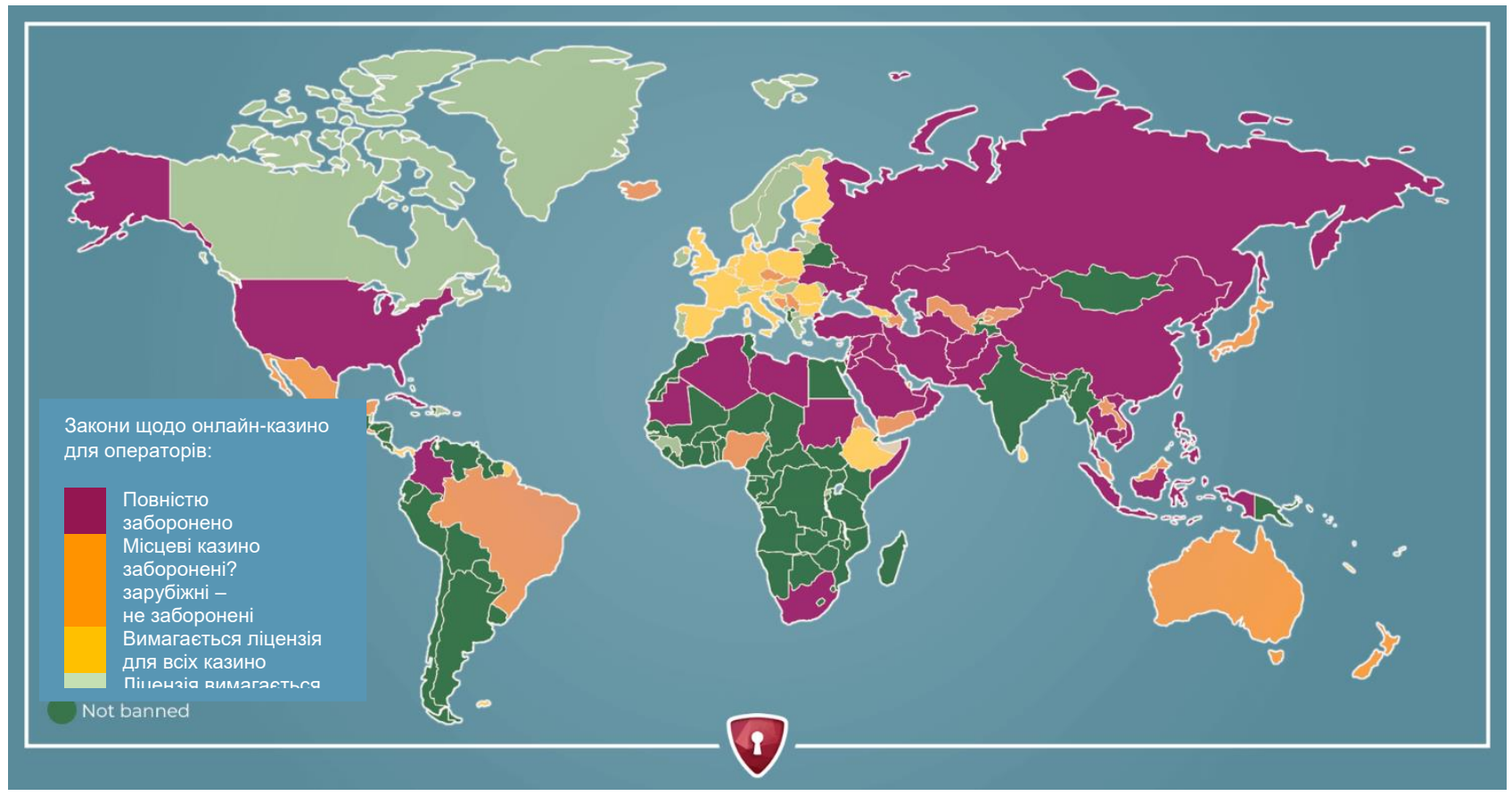

Рис. 1. Карта регулювання азартних ігор, які проводяться онлайн, у 2021 році

\section{Джерело: Slotegrator ${ }^{3}$}

Як вбачається з рис. 1, 32 країни забороняють місцевим операторам онлайн-ігор працювати без ліцензії, але ті гральні сайти, які працюють з-за кордону, можуть легко пропонувати свої послуги місцевим жителям (Сейшельські острови, Вірменія, Домініканська Республіка, Греція, Монако, Норвегія, Канада, Швеція, Швейцарія та ін.); у 32 країнах азартні ігри в Інтернеті дозволені тільки за наявності місцевої ліцензії (Австрія, Данія, Фінляндія, Франція, Великобританія, Нідерланди та ін.); 28 країн забороняють місцевим жителям грати в азартні ігри і блокуватимуть сайти місцевих

\footnotetext{
${ }^{1}$ Vishruti Chauhan (2020). Gambling laws across the world. iPleaders <https://blog.ipleaders.in/gambling-laws-across-world>. (2021, серпень, 29).

2 Там само.

${ }^{3}$ Slotegrator (2021). Where is online gambling legal in 2021? <https://slotegrator.pro/gambling_blog/where-onlinegambling-is-legal.html>. (2021, серпень, 29).
} 
операторів азартних ігор, однак закордонні платформи зможуть працювати вільно, навіть якщо у них немає ліцензії, оскільки ці держави або не хочуть, або не можуть цьому запобігти (Австралія, Бразилія, Нова Зеландія, Мексика, Японія, Сінгапур, Нігерія та ін.); 93 країни не забороняють онлайнказино і не ліцензують їх (Болівія, Уругвай, Венесуела, Багами, Аргентина, Сгипет, Кенія, Туніс, Косово, Гібралтар і ін. $)^{1}$.

Отже, як свідчить світова практика, кожна держава самостійно визначає, які азартні ігри дозволяти, а які забороняти. Як уже зазначалося, вирішення питання про регульовані види азартних ігор нерідко залежить від культурних традицій відповідної країни, проте не лише від них. Зокрема, у наукових працях та інших дослідженнях приводиться низка різноманітних аргументів як на підтримку легального ринку азартних ігор, так і проти існування останнього.

Загалом же, як відмічає О. Гладун, «у наукових дослідженнях традиційно виділяють два основні напрями загроз, за якими гральний бізнес визначається таким, що може заподіяти істотну шкоду: 1) економічна безпека держави та системи господарювання; 2) морально-етична складова життєдіяльності людини та її психічне здоров'я»² ${ }^{2}$ Автор узагальнює такі виділені науковцями загрози першої групи: тісний зв'язок із легалізацією (відмиванням) доходів, одержаних злочинним шляхом, що деякими авторами також вважається виявом організованої економічної злочинності; зв'язок із організованими злочинними угрупуваннями, підвищений розмір завданої шкоди; злочини проти власності заради можливості продовжувати грати; колосальні матеріальні збитки системі господарювання через неконтрольований, масовий і латентний характер, наявність корупційних зв'язків і підпорядкованість організованим злочинним угрупуванням; безконтрольність азартних ігор впливає на формування тіньового сектора економіки, створює необмежені можливості для вчинення шахрайства, легалізації «брудних» коштів, ухилення від оподаткування та хабарництва.

Зокрема, на зв'язку грального бізнесу з легалізацією (відмиванням) доходів, отриманих злочинним шляхом, та діяльністю організованих злочинних угрупувань, оскільки азартні ігри зараховують до найприбутковіших сфер діяльності організованої злочинності, наголошує у своїх poботах 3. Топорецька ${ }^{3}$. Такої ж думки притримується і К. Торгашова, зазначаючи, що гральний бізнес $є$ одним з головних видів діяльності злочинних організованих угрупувань ${ }^{4}$. Крім того, серед інших негативних аспектів легалізації грального бізнесу дослідниця відмічає, що «легалізація грального бізнесу не виключає можливості утворення «тіньових капіталів», які, в свою чергу, використовуються для інших видів протиправної діяльності та для втягнення в такі злочинні організації все більшу і більшу кількість людей».

Водночас, на думку О.Гладуна, твердження про нерозривний зв'язок грального бізнесу в Україні з легалізацією (відмиванням) доходів, одержаних злочинним шляхом (ред. - у період дії заборони на гральний бізнес), є сумнівним з огляду на те, що злочинні кошти, залучені в індустрію грального бізнесу, не могли бути легалізовані у виді прибутку грального закладу чи виграшу від участі в азартних іграх в силу законодавчої заборони останніх. За таких умов, як стверджує науковець, між зайняттям гральним бізнесом і легалізацією доходів, одержаних злочинним шляхом, міг існувати лише односторонній зв'язок: отриманий від організації або участі в азартних іграх дохід міг бути предметом подальшої легалізації з метою недопущення вилучення такого доходу на користь держави ${ }^{5}$. Щодо завдання шкоди через ухилення від оподаткування, автор наголошує, що «значні фінансові втрати держави у виді ненадходження в бюджет відповідних податків і зборів, вартості ліцензій і патентів, спричинені саме офіційною забороною грального бізнесу, а не його нелегальним функціонуванням», а щодо зв'язку між розповсюдженням грального бізнесу та вчиненням

\footnotetext{
1 Там само.

${ }^{2}$ Гладун, О. 3. (2014). Суспільна небезпечність зайняття гральним бізнесом. Наукові записки Інституту законодавства Верховної Ради України, 4, 81-85 <https://instzak.com/index.php/journal/article/view/670/672>.

3 Топорецька, 3. М. (2017). Гральний бізнес як один з основних видів діяльності організованих злочинних угрупувань. Вісник кримінального судочинства, 1, 134-141 <https://scholar.google.com/citations?view_op=view_ citation\&hl=ru\&user=TyTJ174AAAAJ\&sortby=pubdate\&citation_for_view=TyTJ174AAAAJ:IjCSPb-OGe4C $>$. (2021, серпень, 29).

${ }^{4}$ Торгашова, К. О. (2019). Доцільність легалізації грального бізнесу в Україні. Young Scientist», 4 (68), $433-436$ <http://molodyvcheny.in.ua/files/journal/2019/4/97.pdf> (2021, серпень, 29).

${ }^{5}$ Гладун, О. 3. (2014). Суспільна небезпечність зайняття гральним бізнесом. Наукові записки Інституту законодавства Верховної Ради України, 4, 81-85 <https://instzak.com/index.php/journal/article/view/670/672>. (2021, серпень, 29).
} 
корисливих злочинів саме азартними гравцями - такий зв’язок ще не достатньо встановлений та емпіричними даними не підтверджений.

До виділених науковцями загроз другої групи О. Гладун наводить такі: формування стійкої психологічної залежності від гри (лудоманія); способи та форми вчинення, наявність корисливої мотивації, руйнівний вплив на суспільну моральність, здатність викликати в осіб психічну залежність (ігроманію); підрив моральних засад суспільства, сприяння поширенню небезпечних психічних хвороб (ігроманія) ${ }^{1}$. На думку фінських дослідників Т.Датвала, Е.Лінтонен та А.Кону, вплив азартних ігор можна спостерігати на особистому, міжособистісному та суспільному рівнях. Особистий рівень стосується самих гравців, а міжособистісний - людей, близьких до гравця: друзів, сім'̈ та колег по роботі. Вплив може бути індивідуальним або зовнішнім. Індивідуальні впливи викликають вплив на гравця на особистому рівні. Зовнішній вплив впливає на міжособистісний рівень та рівень суспільства/спільноти і стосується тих, хто не обов'язково сам є гравцем².

У питанні наявності негативного впливу азартних ігор та формування залежності у певної категорії гравців науковці практично одностайні, зокрема така позиція підтримується у працях М. Погорецького, 3. Топорецької, А. Овчаренка, К. Торгашової. Через ці значні загрози для суспільства та загального стану здоров’я окремих гравців, азартні ігри є важливою суспільною проблемою. Тож найбільш категорично налаштовані противники азартних ігор вважають, що всі, без винятку, азартні ігри мають бути забороненими, оскільки азартні ігри, в силу своєї природи, спричиняють негативний вплив на схильних до залежності гравців. Не можна не погодитися 3 тим, що азартні ігри формують стійку психічну залежність у деяких гравців. Цей беззаперечний факт на сьогоднішній день визнаний на рівні Всесвітньої організації охорони здоров'я (ВОО3), за рішенням якої у 1980 році залежність від азартних ігор внесена в усі медичні довідники під назвою «лудоманія», від латинського - ludus («лудус, гра»), із присвоєнням їй міжнародного коду F63.0 «Патологічна пристрасть до азартної гри». Ця залежність включена до розладів звичок і потягів та визнана такою ж небезпечною як, наприклад, алкоголізм, комп'ютероманія.

За визначенням міжнародної кваліфікації хвороб, гемблінг, лудоманія надежать до хвороби, що полягає в частих повторних епізодах участі в азартних іграх, що домінує в житті суб’єкта та приводить до зниження соціальних, професійних, матеріальних і сімейних цінностей, втрати належної уваги до своїх обов'язків. Вплив на здоров'я гравця відбувається через формування ігрової залежності, якій сприяє як його бажання отримати адреналін від азарту, так і бажання «відігратися», що штовхає таку особу на продовження гри за будь-яку ціну ${ }^{3}$. Отже, ті, хто категорично проти азартних ігор, вважають, що «ігрова залежність така ж сильна, як і наркотична, коли залежні виносять 3 дому все більш-менш цінне, тільки аби гра ніколи не закінчувалась» ${ }^{4}$.

Варто відмітити, що про небезпеку ігрової залежності та відповідальність держави за те, як відбуваються ці процеси, наголошувалося у різних наукових працях задовго до офіційного визнання BOО3. Так, до прикладу, в енциклопедичному словнику Брокгауза і Ефрона (1890-1907 рр.) щодо небезпеки азартних ігор зазначено: «...Небезпека азартних ігор для суспільства усвідомлювалась у всі часи, і тому прямий обов'язок держави полягає принаймні у спостереженні за тим, щоб такі ігри не відбувалися публічно, не залучали великого кола людей й не позначались, таким чином, тяжко на матеріальному добробуті маси населення. Не лише багаті та забезпечені, а й менш заможні і навіть нижчі класи населення вельми легко підпадають пристрасті до азартних ігор та в гонитві за легкою наживою приносять в жертву свої трудові гроші. Пристрасть до легкої наживи взагалі та до азартної гри особливо властива людству ще в найбільш віддалені часи...» 5 .

Сучасні дослідження, проведені в деяких країнах, підтверджують, що можливості участі в азартних іграх супроводжуються зростанням соціальної нерівності. Хоча домогосподарства

\footnotetext{
1 Там само.

${ }^{2}$ Latvala, T., Lintonen, T., Konu, A. (2019). Public health effects of gambling - debate on a conceptual model. BMC

Public Health, 19, 1077 <https://www.researchgate.net/publication/335082520_Public_health_effects_of_gambling__debate_on_a_conceptual_model>.(2021, серпень, 29).

${ }_{3}^{3}$ Погорецький, М. А. (2015). Розслідування зайняття гральним бізнесом. Київ. Алтера, 8-10.

${ }^{4}$ Павлучкович, Х. (2017). Заборонити не можна узаконити. Чи вдасться уряду легалізувати азартні ігри?

Громадський портал Львова Форпост <https://forpost.lviv.ua/txt/suspilstvo/6902-zaboronyty-ne-mozhnauzakonyty-chy-vdastsia-uriadu-lehalizuvaty-azartni-ihry>. (2021, серпень, 29).

${ }^{5}$ Брокгауз, Ф. А. Ефрон, И. А. Энциклопедический Словарь. Библиотека Вехи <http://www.vehi.net/brokgauz>. (2021, серпень, 29).
} 
3 вищим доходом витрачають в середньому набагато більше на азартні ігри, але бідні домогосподарства при цьому втрачають більшу частку свого доходу. Так, у Німеччині 20\% домогосподарств з найнижчими доходами витрачали на азартні ігри в середньому $12 \%$ свого чистого доходу, порівняно 3 лише $2 \%$ доходу у $20 \%$ домогосподарств 3 найвищими доходами ${ }^{1}$. Тому серед основних переваг вирішення питання азартних ігор шляхом їх тотальної заборони вважається максимальний захист вразливих верств населення від негативних наслідків азартних ігор, розорення та знедолення родин. Проте, як слушно зауважує О. Гладун, «не лише законодавча заборона, але й належний державний контроль грального бізнесу, що передбачає визначення спеціальних обмежень та вимог до суб'єктів, які організовують і провадять азартні ірги, може слугувати надійним бар'єром для зростання існуючої загрози моральності, індивідуальному та громадському здоров'ю»².

Отже, у разі створення дієвого виваженого законодавства у сфері державного регулювання грального бізнесу, держава має можливість не лише забезпечити належний захист і охорону інтересів гравців, а також отримати ряд інших переваг, про які наголошують, зокрема, такі науковці, як А. Овчаренко, К. Торгашова, Р. Грищук, І. Бойно, В. Михайлова. Це стосується економічних вигід у вигляді надходження від податків і зборів, ліцензій, розвитку туризму, збільшення зайнятості населення через створення додаткових робочих місць та офіційної зайнятості (до 2009 року у цій сфері в Україні функціонувало близько 200 тис. робочих місць ${ }^{3}$ ), а також надходження інвестицій для розбудови індустрій розваг та відпочинку, що також матиме позитивний ефект для зайнятості населення. Приклади з інших країн показують, як доходи від провадження азартних ігор використовуються для покращення публічних послуг (наприклад, охорони здоров'я, освіти, культури, соціального забезпечення). Так, у Макао (Китай) завдяки роботі казино місцеві жителі отримують більше соціальних виплат і пільг. Адміністрація району забезпечує осіб старше 65 років безкоштовною медичною допомогою та автобусним перевезенням ${ }^{4}$.

3 іншого боку, у разі недієвого контролю за дотриманням встановлених заборон щодо азартних ігор та враховуючи криміналізацію такого виду діяльності, як правило, гральний бізнес не зникає повністю, а лише переходить до тіньового сектору. У такому разі ніхто не може гарантувати й забезпечити гравцям, зокрема, захист від протиправних дій організаторів азартних ігор, недопущення до гри дітей i інших вразливих груп населення. До прикладу, правові механізми боротьби 3 нелегальними азартними іграми, що діяли в Україні в 2009-2020 роках, не продемонстрували своєї дієвості та не призвели до очікуваних результатів ${ }^{5}$, а обсяги тіньового сектору за різними оцінками складали від 1 млрд грн ${ }^{6}$ до 1 млрд долл. США ${ }^{7}$ на рік.

Грунтовний та всебічний підсумок щодо аргументації на користь легалізації азартних ігор на основі аналізу досвіду правового регулювання сфери азартних ігор у країнах Європейського Союзу, країнах пострадянського простору та України зроблений, на наш погляд, у дослідженні I. Сергієнко. Так, авторка дійшла таких висновків: «майже у всіх країнах європейського континенту гральний бізнес $є$ легальним та бюджетоутворюючим»; «будь-які мораторії на гральну активність не $\epsilon$

\footnotetext{
${ }^{1}$ Latvala, T., Lintonen, T., Konu, A. (2019). Public health effects of gambling - debate on a conceptual model. BMC Public Health 19, 1077 <https://www.researchgate.net/publication/335082520_Public_health_effects_ of_gambling_-_debate_on_a_conceptual_model>. (2021, серпень, 29).

${ }^{2}$ Гладун, О. 3. (2014). Суспільна небезпечність зайняття гральним бізнесом. Наукові записки Інституту законодавства Верховної Ради України, 4, 81-85 <https://instzak.com/index.php/journal/article/view/670/672〉. (2021, серпень, 29).

${ }^{3}$ Овчаренко, А.С. (2018). Легалізація грального бізнесу на теренах України. Молодий вчений, 4 (56), 734-738 <http://molodyvcheny.in.ua/files/journal/2018/4/169.pdf>. (2021, серпень, 29).

${ }^{4}$ Latvala, T., Lintonen, T., Konu, A. (2019). Public health effects of gambling - debate on a conceptual model. BMC Public Health 19, 1077 <https://www.researchgate.net/publication/335082520_Public_health_effects_ of_gambling_-_debate_on_a_conceptual_model>. (2021, серпень, 29).

${ }^{5}$ Костюченко, О. Д. (2020). Правові механізми боротьби з нелегальним азартним іграм в Україні. Наукові перспективи, 6 (6), 85-100 <http://perspectives.pp.ua/index.php/np/article/view/85>. (2021, серпень, 29).

6 Чайка, А., Соколов, О., Стежар, Т. (2019). Гравцям вийти із сутінків. Навіщо Україні легалізація грального бізнесу. Інформаиійне агентсво УНІАН <https://www.unian.ua/society/10726749-gravcyam-viyti-iz-sutinkivnavishcho-ukrajini-legalizaciya-gralnogo-biznesu.html>. (2021, серпень, 29).

${ }^{7}$ Михайлова, В. Д. (2020). Гральний бізнес як механізм тіньової економіки країни. Стратегія інноваційного оновлення економіки Украӥни в сучасних умовах : збірник тез допоповідей Всеукраӥнської науково-практичної Інтернет-конференції (Маріуполь, 26 березня 2020 р.), 189-191 <http://eir.pstu.edu/handle/123456789/26320〉. (2021, серпень, 29).
} 
ефективним інструментом регулювання такої сфери, особливо в умовах їх доступності у мережі інтернет і в сусідніх країнах»; «захистити вразливу частину суспільства від ризиків, пов'язаних з виникненням залежності від азартних ігор, можливо лише через врегулювання цієї сфери життя суспільства і винятково в умовах, коли гральний бізнес працює у правовому полі, відчуває присутність регулятора та конкурентний тиск, що створює реальні стимули дотримуватися вимог закону та принципів соціально відповідальної гри»; «тотальна заборона азартних ігор - це шлях до укріплення корупційної складової в діяльності правоохоронних органів та тінізації азартних ігор 3 подальшим використанням підпільних азартних ігор організованою злочинністю»; «заборона азартних ігор негативно впливає на розвиток інших секторів економіки - туризму, іподромної галузі, конярства, професійного спорту, тощо»; «заборона азартних ігор у певній державі неодмінно призводить до відтоку фінансів із такої країни до країн, у яких азартні ігри легальні, оскільки гравці задовольняють свою потребу в цих країнах безпосередньо або, найчастіше, через мережу інтернет» ${ }^{1}$.

Враховуючи вищезазначені аргументи, ми вважаємо, що прийняття Закону України «Про державне регулювання діяльності щодо організації та проведення азартних ігор» (далі - Закон № 768) стало правильним кроком у напрямі впорядкування суспільних відносин у сфері азартних ігор. Закон № 768, як визначено преамбулою до нього, визначає правові засади здійснення державного регулювання господарської діяльності у сфері організації та проведення азартних ігор в Україні, визначає правові, економічні, соціальні та організаційні умови функціонування азартних ігор 2 .

Так, Закон № 768 передбачає ряд вимог до суб’єктів, що мають намір чи вже здійснюють діяльність у сфері азартних ігор, серед яких можна, зокрема, виділити фінансові (вимоги до розміру статутного капіталу, гарантування здійснення виплати виграшів), кваліфікаційні (визначені законом та ліцензійними умовами), організаційні (до територіального розміщення та приміщення грального закладу), технічні (до обладнання та програмного забезпечення) та інші. У контексті цього дослідження акцентуємо увагу на тих умовах, що стосуються соціальної складової, а саме захисту від негативного впливу азартних ігор, оскільки це питання, як встановлено вище, викликає найбільшу зацікавленість та занепокоєння суспільства.

Законом № 768 встановлені зобов’язання та заборони для організаторів азартних ігор, у тому числі які спрямовані на захист гравців від надмірного втягнення у гру. Зокрема, організатори азартних ігор зобов'язані:

- вживати заходів для недопущення до гральних закладів та до участі в азартних іграх осіб, які не досягли 21-річного віку, та осіб, стосовно яких наявні обмеження згідно з Законом № 768;

- відшкодувати фінансову шкоду в розмірі десятикратного розміру програшу особам, участь яких в азартних іграх заборонена цим та іншими законами, на їх вимогу або на вимогу членів сім’і таких осіб, що заподіяна у разі не забезпечення неможливості участі таких осіб в азартних іграх;

- дотримуватися принципів відповідальної гри, зокрема: забезпечувати ідентифікацію гравців та відвідувачів угральному закладі та під час провадження діяльності в мережі Інтернет; не допускати до участі в азартних іграх осіб, яким обмежено доступ до участі в азартних іграх, та осіб, у яких виражена ігрова залежність (лудоманія); утримуватися від надання гравцям будь-яких бонусних виплат, подарунків та/або надання товарів (послуг) у будь-якій формі, використання інших видів заохочення, надання яких прямо чи опосередковано обумовлено настанням факту програшу гравця у відповідній азартній грі;

- забезпечити розміщення на вебсайті інформації про реальний час, зокрема шляхом розміщення годинника, що відображає актуальний час, на кожній сторінці вебсайту;

- розмістити у місцях провадження діяльності у вільному доступі для гравців та відвідувачів інформаційні матеріали щодо ігрової залежності та відповідальної гри, зокрема про обмеження віку гравця, шанси на виграш, принципи відповідальної гри, місця, де можна отримати допомогу в разі гральної залежності, викладені державною мовою та перекладені англійською мовою;

- надавати гравцям шляхом розміщення у відкритому доступі інформацію про діяльність організацій, лікувальних закладів та/або медичних працівників, які лікують ігрову залежність.

\footnotetext{
${ }^{1}$ Сергієнко, І.В., Фомін, І.Ю., Хорольський, Р.Б. (ред.) (2015). Правове регулювання грального бізнесу: європейський досвід, практика в пострадянських країнах, перспективи України. Київ: Юридична компанія «Фомін, Сергієнко та партнери», 119-120.

2 Закон про державне регулювання діяльності щзодо організаиії та проведення азартних ігор, 2020 (Верховна Рада України). Офіційний сайт Верховної Ради України <https://zakon.rada.gov.ua/laws/show/768-20\#Text> (2021, вересень, 14).
} 
Серед основних обмежень варто зазначити, що організаторам азартних ігор заборонено:

- приймати ставки в азартній грі в осіб, які не можуть бути гравцями відповідно до цього Закону № 768;

- примушувати відвідувачів до гри;

- пропонувати або давати алкогольні напої, пиво, слабоалкогольні напої чи тютюнові вироби безкоштовно або як винагороду за участь в азартній грі, а також майно, володіння або розпорядження яким передбачає отримання дозволів або ліцензій;

- приймати ставки у кредит (із розстроченням платежу) або з наступною оплатою, крім оплати ставки кредитними або дебетовими картками за наявності авторизації платежу;

- надавати гравцю позики для участі у грі;

- розміщувати у гральних закладах банківські та кредитні установи, ломбарди, банкомати, пункти обміну валют.

Крім того, законодавчо встановленні певні обмеження щодо реклами азартних ігор (внесені відповідні зміни в Закон України «Про рекламу»). Зокрема, реклама заборонена:

- на радіо та телебаченні, у тому числі за допомогою кабельного, супутникового, IP-телебачення, онлайн-телебачення, мобільного телебачення, цифрового ефірного телебачення та інших засобів передавання сигналу, у період з 6 до 23 години;

- у наукових, науково-популярних, навчальних, громадсько-політичних, довідкових, літературно-художніх виданнях, виданнях для дітей та юнацтва та інших виданнях (крім спеціалізованих видань, присвячених азартним іграм);

- в усіх друкованих засобах масової інформації (крім спеціалізованих видань, присвячених азартним іграм);

- на зовнішніх та внутрішніх поверхнях транспортних засобів та метрополітену;

- засобами зовнішньої реклами;

- на товарах (у тому числі одязі), призначених переважно для осіб віком до 21-річного віку;

- в місцях проведення розважальних, театрально-концертних, спортивних та інших заходів для осіб, які не досягли 21-річного віку.

Також закон вимагає, щоб реклама азартних ігор не формувала думку, що виграти в азартну гру легко, а участь в азартних іграх може бути джерелом доходів чи альтернативою роботі, не містила недостовірну інформацію, не була хибною, неправдивою або удаваною та супроводжувалася попереджувальним текстом чорного кольору на білому фоні «Участь в азартних іграх може викликати ігрову залежність. Дотримуйтеся правил (принципів) відповідальної гри» обсягом не менше 15 відсотків площі всієї реклами. Крім того, заборонено спрямовувати рекламу на вразливі групи населення (неповнолітні особи, малозабезпечені особи, особи, хворі на психічні захворювання), використовувати в такій рекламі осіб, які не досягли 21-річного віку, у тому числі як фотомоделей, та спонсорувати теле-, радіопередачі, театрально-концертні та інші заходи, призначені переважно для осіб, які не досягли 21 року (крім трансляції спортивних заходів), з використанням знаків для товарів і послуг, інших об'єктів права інтелектуальної власності, під якими провадиться діяльність 3 організації та проведення азартних ігор.

Як бачимо, Закон № 768 містить значний перелік обмежень та запобіжників, покликаних створити умови, за яких азартна гра не повинна становити загрози для безпеки та добробуту громадян. Водночас, на наш погляд, вбачається доцільним запровадити додатково ще декілька слушних обмежень, а саме:

- заборона здійснення ставок в азартних іграх за кредитні кошти (кредитний ліміт, овердрафт та інші боргові інструменти) - таких захід в ситуації, коли банки масово пропонують доволі великі кредитні ліміти, не вимагаючи, та, відповідно, не перевіряючи платоспроможність клієнтів, може запобігати безконтрольному спрямуванню таких боргових коштів на азартну гру, що матиме наслідком завдання незворотних збитків численним родинам;

- обмеження доступу до азартних ігор осіб, у яких $\epsilon$ непогашені фінансові зобов'язання таких захід, за умови наявності в особи непогашених фінансових зобов'язань, не дозволить створювати нові та далі затягуватися у боргову прірву;

- обмеження суми витрат гравця на гру у певний період (день, місяць тощо) - такий захід слугуватиме додатковим запобіжником неконтрольованих видатків на гру за умови, коли особа, перебуваючи в стані азарту, бажатиме, наприклад, відігратися;

- обмеження максимального розміру ставок - такий захід слугуватиме додатковим запобіжником як щодо відмивання нелегальних грошових коштів, так і щодо одномоментного значного програшу; 
- заборона продавати у приміщенні гральних закладів алкогольні напої гравцям - такий захід спрямований на підтримання гравців у адекватному стані, оскільки, як відомо, алкоголь приглушує захисні функції особи;

- повна заборона реклами - такий захід убезпечить від отримання інформації про принади азартних ігор широкого кола осіб за умови, що хоч визначені законом заборони виглядають не погано, проте на практиці контроль щодо дотримання цих заборон, ймовірніше за все, буде складно здійснювати i, як наслідок, він може бути не достатньо дієвим.

Доцільність запровадження цих обмежень обгрунтовується також «гіпотезою адаптації», згідно з якою відкриття доступу до азартних ігор там, де вони були заборонені, призводить до набагато більших негативних наслідків, ніж там, де азартні ігри були широко доступні. Недавні дослідження також показують, що загальні показники шкоди стабілізуються, коли кількість учасників азартних ігор спадала після відкриття до них доступу, але для деяких груп негативні наслідки зростали, хоча їхня участь в азартних іграх 3 часом зменшувалася ${ }^{1}$. Тож такі додаткові заходи, на наш погляд, створять додаткові умови для підвищення соціальної ролі та соціальної відповідальності організаторів азартних ігор, не дозволять населенню створювати неконтрольовані борги та убезпечать від бажання відігратися за будь-яку ціну, завдаючи незворотної шкоди собі та своїм сім'ям.

Висновки та напрями подальших досліджень. Отже, вплив азартних ігор на суспільство $є$ водночас позитивним і негативним і залежить від ряду факторів, зокрема від середовища їх здійснення, того, які види азартних ігор доступні, а також від дієвості політики держави у сфері регулювання азартних ігор. Кожна держава самостійно визначає, які азартні ігри дозволяти, а які забороняти. Вирішення цього питання нерідко залежить від культурних традицій відповідної країни, проте не лише від них. На нашу думку, оптимальним варіантом вирішення питання азартних ігор є їх легалізація у прийнятний для конкретного суспільства спосіб, що враховує баланс інтересів держави, бізнесу та суспільства. Перевагою такого підходу вважається, що за умови створення належної системи організації діяльності з проведення азартних ігор та контролю з боку регуляторних органів, це убезпечить від здійснення такої діяльності безконтрольно, а відтак без порушення прав гравців, при цьому надходження від такої діяльності можуть направлятися на фінансування відповідних соціальних проєктів та програм.

У цьому контексті дуже важливим моментом у виборі механізмів державного регулювання азартних ігор має відігравати врахування проблеми негативного впливу азартної гри на вразливі групи з метою визначення оптимальних меж функціонування ігор на гроші, запровадження достатніх та дієвих превентивних механізмів і програм, а також культивування в суспільстві соціально відповідальної гри. Запропоновані нами додаткові запобіжні заходи, спрямовані на підвищення соціальної відповідальності організаторів азартних ігор, слугуватимуть надійним запобіжником для того, щоб азартна гра як вид розваги не перетворювалася на загрозу для безпеки та добробуту громадян.

Враховуючи, що азартні ігри в Україні, після тривалої перерви, лише нещодавно функціонують у правовому полі, подальші дослідження доцільно проводити в аспекті оцінки кількісного та якісного впливу визначених законодавством механізмів регулювання азартних ігор на різні сфери суспільного життя.

\section{References:}

1. Pavluchkovych, Kh. (2017). Zaboronyty ne mozhna uzakonyty. Chy vdastsia uriadu lehalizuvaty azartni ihry [Prohibition cannot be legalized. Will the government be able to legalize gambling]? Hromadskyi portal Lvova Forpost [Public portal of Lviv Outpost]. <https://forpost.lviv.ua/txt/suspilstvo/6902-zaboronyty-ne-mozhnauzakonyty-chy-vdastsia-uriadu-lehalizuvaty-azartni-ihry> (2021, September, 14). [in Ukrainian].

2. Pohoretskyi, M. A. (2015). Rozsliduvannia zainiattia hralnym biznesom [Investigation of gambling]. Kyiv. Altera. [in Ukrainian].

3. Pohoretskyi, M. A., Toporetska, Z. M. (2014). Hralnyi biznes: istoriia ta pravove rehuliuvannia [Gambling: history and legal regulation]. Kyiv. VD Dakor. $92 \mathrm{~s}$. [in Ukrainian].

\footnotetext{
${ }^{1}$ Latvala, T., Lintonen, T., Konu, A. (2019). Public health effects of gambling - debate on a conceptual model. BMC Public Health 19, 1077 <https://www.researchgate.net/publication/335082520_Public_health_effects_ of_gambling_-_debate_on_a_conceptual_model>. (2021, серпень, 29).
} 
4. Hladun, O. Z. (2014). Suspilna nebezpechnist zainiattia hralnym biznesom [The social danger of gambling]. Naukovi zapysky Instytutu zakonodavstva Verkhovnoi Rady Ukrainy [Scientific Notes of the Institute of Legislation of the Verkhovna Rada of Ukraine], 4, 81-8 <https://instzak.com/index.php/journal/article/view/670/672> (2021, September, 14). [in Ukrainian].

5. Riabchuk, S. V. (2018). Zahalnosotsialne zapobihannia hralnomu bznesu v Ukraini [General social prevention of gambling business in Ukraine]. Pravo i suspilstvo [Law and society], 3, 230-235

<http://www.pravoisuspilstvo.org.ua/archive/2018/3_2018/part_2/39.pdf> (2021, September, 14). [in Ukrainian].

6. Ovcharenko, A. Ie. (2018). Lehalizatsiia hralnoho biznesu na terenakh Ukrainy [Legalization of gambling business in Ukraine]. Molodyi vchenyi [Young scientist], 4 (56), 734-738

<http://molodyvcheny.in.ua/files/journal/2018/4/169.pdf> (2021, September, 14). [in Ukrainian].

7. Torhashova, K. O. (2019). Dotsilnist lehalizatsii hralnoho biznesu v Ukraini [Expediency of legalization of gambling business in Ukraine]. Young Scientist, 4 (68), 433-436 〈http://molodyvcheny.in.ua/files/journal/2019/4/97.pdf〉 (2021, September, 14). [in Ukrainian].

8. Mykhailova, V. D. (2020). Hralnyi biznes yak mekhanizm tinovoi ekonomiky krainy [Gambling as a mechanism of the country's shadow economy.]. Stratehiia innovatsiinoho onovlennia ekonomiky Ukrainy v suchasnykh umovakh : zbirnyk tez dopopovidei Vseukrainskoi naukovo-praktychnoi Internet-konferentsii (Mariupol, 26 bereznia $2020 \mathrm{r}$.) [Strategy of innovative renewal of the economy of Ukraine in modern conditions: a collection of abstracts of the All-Ukrainian scientific-practical Internet conference (Mariupol, 2020, March, 26)], 189-191 <http://eir.pstu.edu/handle/123456789/26320> (2021, September, 14). [in Ukrainian].

9. Hyshchuk, R. M., Boiko, I. D. (2017). Osoblyvosti funktsionuvannia hralnoho biznesu v yevropeiskykh krainakh ta yikhnii dosvid u konteksti rozvytku turyzmu v Ukraini [Peculiarities of gambling business functioning in European countries and their experience in the context of tourism development in Ukraine]. Visnyk Chernivetskoho torhovelno-ekonomichnoho instytutu [Bulletin of the Chernivtsi Trade and Economic Institute], 1-2 (65-66), 258-270 <http://www.chtei-knteu.cv.ua/herald/content/download/archive/2017/v1-2/NV-2017-v1-2_27.pdf> (2021, September, 14). [in Ukrainian].

10. Vestnyk yhornoho byznesa [Bulletin of the gambling business] (2021). Yhornyi byznes v myre [Gambling business in the world]. <http://vib.adib92.ru/main.mhtml?PubID=9164\&Part=12> (2021, September, 14). [in Russian].

11. Vishruti Chauhan (2020). Gambling laws across the world. iPleaders <https://blog.ipleaders.in/gambling-laws-across-world> (2021, September, 14). [in English].

12. Panasytska, O., Ivantsova, A., Chek, V. (2021). Ihry v zakoni: yak rehuliuiut hralnyi biznes v Ukraini ta u sviti [Games in law: how gambling is regulated in Ukraine and in the world]. Voks Ukraina [Vox Ukraine] <https://voxukraine.org/igri-v-zakoni-yak-regulyuyut-gralnij-biznes-v-ukrayini-ta-u-sviti> (2021, September, 14). [in Ukrainian].

13. Slotegrator (2021). Where is online gambling legal in 2021? <https://slotegrator.pro/gambling_blog/where-onlinegambling-is-legal.html> (2021, September, 14). [in English].

14. Latvala, T., Lintonen, T., Konu, A. (2019). Public health effects of gambling - debate on a conceptual model. BMC Public Health, 19, 1077 <https://www.researchgate.net/publication/335082520_Public_health_effects_ of_gambling_-_debate_on_a_conceptual_model> (2021, September, 14). [in English].

15. Brokgauz, F. A. Efron, I. A. (2021). Jenciklopedicheskij Slovar [Encyclopedic Dictionary]. Biblioteka Vehi [Milestones Library] <http://www.vehi.net/brokgauz> (2021, September, 14). [in Russian].

16. Kostiuchenko, O. D. (2020). Pravovi mekhanizmy borotby z nelehalnym azartnym ihram v Ukraini [Legal mechanisms for combating illegal gambling in Ukraine]. Naukovi perspektyvy [Scientific perspectives], 6 (6), 85-100 <http://perspectives.pp.ua/index.php/np/article/view/85> (2021, September, 14). [in Ukrainian].

17. Chaika, A., Sokolov, O., Stezhar, T. (2019). Hravtsiam vyity iz sutinkiv. Navishcho Ukraini lehalizatsiia hralnoho biznesu [Players get out of the twilight. Why Ukraine legalizes gambling]. Informatsiine ahentstvo UNIAN [UNIAN news agency] <https://www.unian.ua/society/10726749-gravcyam-viyti-iz-sutinkiv-navishcho-ukrajinilegalizaciya-gralnogo-biznesu.html> (2021, September, 14). [in Ukrainian].

18. Serhiienko, I. V., Fomin, I. Iu., Khorolskyi, R. B. (ed.) (2015). Pravove rehuliuvannia hralnoho biznesu: yevropeiskyi dosvid, praktyka v postradianskykh krainakh, perspektyvy Ukrainy [Legal regulation of gambling business: European experience, practice in post-Soviet countries, prospects of Ukraine]. Kyiv: Fomin, Sergienko \& Partners Law Firm. [in Ukrainian].

19. Zakon pro derzhavne rehuliuvannia diialnosti shchodo orhanizatsii ta provedennia azartnykh ihor, 2020 (Verkhovna Rada Ukrainy) [Law on State Regulation of Activities Concerning the Organization and Conduct of Gambling, 2020 (Verkhovna Rada of Ukraine)]. Ofitsiinyi sait Verkhovnoi Rady Ukrainy [Official site of the Verkhovna Rada of Ukraine] <https://zakon.rada.gov.ua/laws/show/768-20\#Text> (2021, September, 14). [in Ukrainian]. 